\title{
PELAKSANAAN PROGRAM KELUARGA BERENCANA (KB) DI KECAMATAN BARAKA KABUPATEN ENREKANG
}

\author{
Jusliati $^{1,}$ Abd. Kadir Adys ${ }^{2,}$ Nasrul Haq ${ }^{3}$ \\ ${ }^{1)}$ Program Studi Ilmu Administrasi Negara Unismuh Makassar \\ 2) Program Studi Ilmu Administrasi Negara Unismuh Makassar \\ ${ }^{3)}$ Program Studi Ilmu Administrasi Negara Unismuh Makassar
}

\begin{abstract}
This study aimed to find out. Implementation of Family Planning Program in Baraka District, Enrekang Regency. The type of research used in this study was descriptive qualitative research with phenomenology that was inductive. Data collection techniques used by researchers were interviews with eight informants, observation, and documentation. Data analysis techniques used were data reduction, data presentation, data presentation, and conclusion. Data validity was used triangulation that was source triangulation, triangulation time, and triangulation technique. The results of this study indicated that the Family Planning Program seuccessfully run well wuth evidence that the satisfaction of people who had used KB, but still needed to improve access to quality services in Family Planning Program in Baraka District Enrekang Regency Keywords implementation of Family Planning Program (KB).
\end{abstract}

Key words: The implementation of Family Planning Program (KB).

\begin{abstract}
ABSTRAK
Penelitian ini bertujuan untukmengetahui. Pelaksanaan Program Keluarga Berencana di Kecamatan Baraka Kabupaten Enrekang. Jenis penelitian yang digunakan dalam penelitian ini adalah jenis penelitian deskriptif kualitatif dengan tipe fenomonologi yang bersifat induktif. Teknik pengumpulan data yang yang digunakan peneliti adalah wawancara dengan informan sebanyak delapan orang, observasi, dan dokumentasi. Teknik analisis data yang digunakan adalah reduksi data, penyajian data, dan penarikan kesimpulan. Keabsahan data digunakan triangulasi yaitu triangulasi sumber, triangulasi waktu, dan triangulasi teknik. Hasil penelitian ini menunjukkan bahwa Program Keluarga Berencana berhasil berjalan dengan baik dengan bukti bahwa adanya kepuasan masyarakat yang telah menggunakan KB, namun masih perlu adanya pembenahan akses kualitas pelayanan dalam Program Keluarga Berencana di Kecamatan Baraka Kabupaten Enrekang.
\end{abstract}

Kata Kunci: Pelaksanaan Program Keluarga Berencana (KB). 


\section{PENDAHULUAN}

Program Keluarga Berencana merupakan produk dari Kebijakan Publik Pemerintah, dimana pemerintah sebagai (public servent) dituntut untuk melayani masyarakat secara optimal yaitu dengan pelayanan prima kepada masyarakat. Seiring dengan terjadinya reformasi politik pemerinthan yang ditandai dengan penerapan system pemerintahan berdasarkan otonomi daerah, terjadi pula pergeseran paradigma dalam pelaksanaan korban $\mathrm{KB}$ dilapangan mempengaruhi gerak dinamis program KB Nasional.

Program KB Nasional yang didaerah sebelum desentralisasi menjadi primadona pembangunan sumber daya manusia terutama dalam peningkatan kesejahteraan ibu dan anak, sekarang ini pelaksanaanya menjadi sangat tergantung kepada kebijakan strategi pemangku kebijakan yang ada di daerah, maka dengan diterbitkannya PP No. 38 Tahun 2008 Tentang organisasi Perangkat Daerah, Keluarga Berencana (KB) dan
Keluarga sejahtera (KS) merupakan satu diantara 28 urusan wajib.

Program Keluarga Berencana Nasioanal diatur dalam UndangUndang Nomor 52 Tahun 2009 tentang Perkembangan Kependudukan dan Pembangunan. Keluarga Dalam UU Nomor 52 Tahun 2009 disebutkan bahwa yang dimaksud dengan Keluarga Berencana (KB) adalah upaya mengatur kelahiran anak, jarak dan usia ideal melahirkan, mengatur kehamilan, melalui promosi, perlindungan dan bantuan sesuai dengan hak produksi untuk mewujudkan keluarga yang berkualitas.

Pelaksanaan program KB yang dilaksanaan oleh BKKBN dirasakan telah membuahkan hasil. Walaupun masih belum berhasil benar tetapi telah mengalami kemajuan yang cukup besar. Banyaksekali kebiasaan yang ada di masyarakat yangtelahberubah.Program $\quad \mathrm{KB}$ bertujuan untuk mengontrol jumlah penduduk yang ada di negara ini. Jumlah penduduk yang ada di negeri ini sudah lumayan cukup besar. Untuk 
suatu negara, penduduk kita termasuk besar yakni lebih dari dua ratus juta jiwa.Angka yang cukup tinggi. Oleh karena itu pemerintah berusaha menekan laju pertumbuhan penduduk dengan program KB.

Masalah Keluarga Berencana (KB) merupakan masalah yang ada hubunganya

dengan kesehatan, pendidikan, lapanga n kerja, sumber ekonomi, katahanan na sional, pembangunan, kriminalitas, mo ral, kelestarian lingkungan dan kepend udukan.Pada masah kesehatan, dalam sebuah keluarga inti (nuclear family) wanita biasanya menghadapi masalah, yaitu masalah reproduksi.Kesehatan wanita secara langsung mempengaruhi kesehatan anak yang dikandung dan yang dilahirkan, maka sering terlupakannya kesehatan wanita dalam suatu keluarga.yang tidak pria hadapi. Adapun masalah lain dalam berkeluarga yaitu mempunyai anak yang bermasalah kesehatanya seperti gizi buru. Sehingga disini masyarkata atau seorang ibu mengalami suatu maslah dan sulit di tangani.
Masalah kebijakan pendidikan bahwa, setiap keluarga yang memiliki pendidikan rendah pasti tidak akan memperdulikan bahwa pentingnya pendidikan formal dan non-formal. Keluarga yang tidak perduli pendidikan akan membentuk anak menjadi mental minta-minta dan akhirnya putus sekolah. Hal ini bisa saja terjadi bila tidak ada pengaturan jumlah anak serta jarak kehamilan ibu, menyebabkan bertambahnya beban yang harus dikeluarkan untuk biaya pendidikan.

Kebijakan tersebut memiliki masalah lapangan kerja terliat bahwa, bayak keluarga yang meluluskan anaknya sekolah untuk mendapatkan dan mencari lapangan pekerjaan yang mampu menyerapnya. Sedangkan sosial ekonomi, percepatan pertumbuhan ekonomi akan menjadi terhambat apabila bayak dari keluarga yang tidak membentuk anak mereka untuk mandiri, . Keluarga perlu merencanakan keberlangsungan hidup penerusnya, dalam arti seorang untuk harus ada perubahan minimal lebih baik dilihat dari mata 
pencaharian kedua orang tuanya, sehingga perubahan stratifikasi sosial ada dan tidak menurun.

Sebuah kebijakan tidak bisa dilepas begitu saja. Kebijakan harus diawasi, dan salah satu mekanisme pengawasan tersebut disebut sebagai kebijakan. Pelaksanaan biasanya ditujukan untuk menilai sejauh mana keefektifan kebijakan publik guna dipertanggung jawabkan kepada konstituennya

Menurut Thomas Dye Zainal Said (2012:170) Pelaksanaan adalah melihat sebagai nilai masa kini dan masa yang akan datang. Dalam hal ini, pengklasifikasian unsure-unsur pelaksanaan atas nilai manfaatnya, biaya, dalam dimensi waktu, serta antara kelompok sasaran dan non sasaran, sedikit bayak mencerminkan pandangan yang biasa digunakan dalam ekonomi politik.

\section{Program pemerintah yang} mempunyai perbedaan-perbedaan yang bersifat penting dalam spesifikasi obyeknya, teknik pengukurannya dan metode analisis. Evaluasi dapat diartikan sebagai usaha-usaha untuk menyelidiki apakah program yang dilaksanakan sesuai dengan apa yang diinginkan ataukah tidak.

Berdasarkan restra BPPKB, UPT BPPKB berkedudukan di kecamatan, dan mempunyai tugas pokok melaksanakan sebagai kegiatan yang bersifat tekhnis operasional dan atau kegiatan teknis menunjang dalam melakukan kegiatan pemberdayaan perempuan dan keluarga berencana. Dalam melaksanakan tugasnya dibantu pejabat fungsional, yang selanjutnya disebut sebagai Penyuluh Keluarga Berencana (PKB) atau Petugas Lapangan Keluarga Berencana (PLKB).

Pada tingkat desa juga terdapat pengusrus $\mathrm{KB}$, dengan harapan karena lebih dekat dengan warga masyarakat sehingga masyarakat sadar akan pentingnya KB. Dari Kecamatan Baraka ini pada tahun 2015 kini masih belum maksimal dari masyarakat yang menggunakan $\mathrm{KB}$ karena mereka masih canggung dan belum mengetahui apa itu 
KB. Maka di ambil keputusan untuk menciptakan program kerja untuk bertugas lapangan keluarga berencana turun langsung dari lapangan untuk memberikan arahan kepada masyarakat desa.

Menurut Soemarwoto dalam Giroth (2004), menyatakan bahwa dampak adalah suatu perubahan yang terjadi sebagai akibat suatu aktifitas. Selanjutnya Soemarwoto menjelaskan: aktifitas tersebut bias bersifat alamia, berupa kimia, fisik maupun biologi, dapat dilakukan oleh, manusia berupa analisis dampak lingkungan, pembangunan dan perencanaan.

Menurut Ary Sulistyawati (2011:13) Program Keluarga Berencana (Family Planning, Planned Parenthood) merupakan suatu usaha untuk menjarangkan atau merencanakan jumlah dan jarak kehamilan dengan menggunakan kontrasepsi

Program Keluarga Berencana merupakan usaha langsung yang bertujuan untuk mengurangi tingkat kelahiran melalui penggunaan alat kontrasepsi.Berhasil atau tidaknya Pelaksaan Program Keluarga Berencana akan menetukan pula berhasil atau tidaknya usaha untuk mewujudkan kesejahteraan bangsa Indonesia.

Pelaksanaan adalah suatu tindakan atau pelaksanaan dari sebuah rencana yang sudah disusun secara matang dan terperinci, implementasi biasanya dilakukan setelah pelaksanaan di anggap siap. Secara sederhana bisa di artikan penerapan. Browne dan Wildavsy mengemukakan bahwa pelaksanaan adalah perluasan aktivitas yang saling menyesuaikan.

Pelaksanaan merupakan aktifitas atau usaha-usaha yang dilaksanakan untuk melaksanakan semua rencana dan kebijaksanaan yang telah dirumuskan dan ditetapkan dengan dilengkapi segalah kebutuhan, alat-alat 
yang diperlukan, siapa yang pelaksana merupakan upaya untuk melaksankan, dimana tempat menjadikan perencanaan menjadi pelaksanaannya dimulai dan kenyataan, dengan melalui berbagai bagaimana cara yang harus pengarahan dan motivasi agar setiap dilaksanakan, suatu proses rangkaian karyawan dapat melaksanakan tindak lanjut setelah program atau kegiatan secara optimal sesuai dengan kebijaksanaan ditetapkan yang terdiri atas pengambilan keputusan, langkah yang strategis maupun operasional atau kebijaksanaan menjadi kenyataan guna mencapai sasaran dari program yang ditetapkan semula.

Menurut George R. Terry 2001 mengemukakan bahwa pelaksanan merupakan menggerakkan anggotaanggota kelompok sedemikian rupa hingga meraka berkeinginan dan berusaha untuk mncapai sasaran perusahaan dan sasaran anggotaanggota tersebut oleh karena para anggota itu juga ingin mencapai sasarn tersebut. Dari pengertian di atas peran, tugas dan tanggung jawabnya.

Program Keluarga Berencana memiliki beberapa metode kontrasepsi dalam pelayanan $\mathrm{KB}$, yaitu Kontrasepsi Suntik, Kondom, Pil Konrasepsi, IUD (Intra Uterine Device) atau Spiral, Susuk (inplant), Vasektomi MOP (Metode Operasi Pria) dan Tubektomi MOW (Metode Operasi Wanita) atau biasa disebut Sterilisasi. Metode kontrasepsi yang telah tersedia dapat dipilih oleh para peserta KB pasangan suami istri dengan minat kedua belah pihak agar dapat terwujudnya kesehatan reproduksi dalam sebuah keluarga.

Metode Kontrasepsi Jangka Panjang (MKJP) adalah salah satu dari sekian bayak metode kontrasepsi yang 
dipergunakan dibeberapa Negara di dunia saat ini.Kontrasepsi ini sudah digunakan sebagai sarana hidup sehat, yakni sarana untuk menurunkan tingkat kelahiran dan kesuburan manusia.Secara langsung maupun tidak langsung hal ini berhubungan dengan tingkat kesejahteraan keluarga.Kontrasepsi telah merupakan kebutuhan manusia saat ini yang tidak berbeda dengan kebutuhan dasar lainnya.

\section{METODE PENELITIAN}

Penelitian ini dilaksanakan kurang lebih selama dua bulan. Penelitian ini dilakukan di Kantor Balai Penyuluhan Keluarga Berencana (KB) Kabupaten Enrekang. Disertai dengan pertimbangan bahwa melakukan penelitian mengenai Program Keluarga Berencana (KB) adalah untuk mengetahui bagaimana kinerja pemerintah dan dinas yang terkait dalam Program Keluarga Berencana (KB) dan mengetahui sistem pelayanan yang telah ditetapkan apakah sudah berjalan dengan baik.

Jenis penelitian yang digunakan dalam penelitian ini adalah metode kualitatif yang berusaha menjelaskan sedetail mungkin objek dan maslah penelitian berdasarkan fakta yang diperoleh dilapangan. Jumlah informan pada penelitian ini sebanyak 8 orang informan yaitu: kordinator PBKB 1 orang,Bidan 2 orang, Kader Pos KB 2 Orang dan Masyarakat Pengguna KB 2 orang di Kecamatan Baraka.

Sumbe data adalah segala sesuatu yang dapat memberikan informasi mengenai data. Pengumpulan data dilakukan melalui beberapa teknik yaitu wawancara mendalam, observasi dan dokumentasi. Untuk menjamin keabsahan data maka dilakukan pengumpulan data dengan mengunakan teknik penelitian ini dapat menggunakan tipe studi kasus (case studies) yaitu penelitian yang mendalam tentang individu, satu organisasi, satu program kegiatan, dan sebagainya dalam waktu tertetu.Tujuannya untuk memperoleh 
deskripsi yang utuh dan mendalam dari suatu entitas.

Analisis data ialah langkah selanjutnya untuk mengolah data dari hasil penelitian menjadi data, dimana data diperoleh, dikerjakan dan dimanfaatkan sedemikian rupa untuk menyimpulkan persoalan yang diajukan dalam menyusun hasil penelitian.

Dalam waktu yang tidak ditentukan sampai data yang diperoleh jenuh dan tidak ada lagi data yang baru pada tahap pelaksanaan peneliti akan melakukan proses pengumpulan data, klarifikasi data, analisis data, dan penarikan kesimpulan.

\section{HASIL DAN PEMBAHASAN}

Sebenarnya semua masalah sosial yang ada di masyarakat yang ada bisa di atasi. Penyelesaian yang ada bisa diatasi jika adanya pemerataan kesejahteraan sosial yang benar-benar merata. Namun semua itu tidak bisa dilakukan karena masih belum meratanya kesejahteraan sosial masyarakat yang ada di negeri ini. Maka tidak heran jika Program KB lah yang dipilih demi mensejahterakan masyarakat.

Pelaksanaan Program Keluarga Berencana (KB)Pembahasan pada penyajian data merupakan hasil analisis dan fakta yang peneliti temukan dilapangan serta disesuaikan dengan teori yang digunakan Peneliti menggunakan teori implementasi kebijakan dimana kebijakan publik merupakan sebagai suatu proses yang menggambarkan berdasarkan kcriteriakriteria kebijakan publik yaitu efektifitas, efisiensi, kecukupan, perataan, responsifitas, dan ketepatan. Adapun pembahasan yang dapat peneliti paparkan sebagai berikut.

Dimensi efektifitas merupakan suatu yang berkaitan dengan target pencapian tujuan dari usaha-usaha yang dilakukan. program Keluarga Berencana metode vasektomi, tubektomi, pil, implant, dan suntik merupakan pencapaian target jumlah peserta KB serta hambatan yang dihadapi dalam pelaksanaan Program KB ditiap metodenya, Berikut temuan di lapangan . 
Apakah hasil yang diinginkan telah tercapai dalam hal ini adalah Unit Pelayanan. Efektivitas merupakan hubungan antara output dengan tujuan, semakin besar kontribusi (sumbangan) output terhadap pencapaian tujuan, maka semakin efektif organisasi, program atau kegiatan. Membahas masalah ukuran efektivitas memang sangat bervariasi tergantung dari sudut terpenuhinya beberapa kriteria akhir. Efektivitas merupakan suatu standar akan terpenuhinya mengenai sasaran dan tujuan yang akan dicapai serta menunjukan pada tingkat sejauhmana organisasi, $\quad$ program/kegiatan melaksanakan fungsi-fungsinya secara optimal.

Mengenai hambatan program KB, yaitu hambatan terdapat pada calon peserta KB itu sendiri karena masih memiliki pola pikir yang sederhana, acuh terhadap kesehatan ibu dan anak, sebagai peneliti dapat menarik kesimpulan bahwa hampir seluruh tahapan dalam program KB pelaksana yang terkait sudah menjalankan tugas dan fungsinya dengan baik, tapi dalam hal konteks keberhasilan mengalami hambatan yang dipengaruhi oleh masyarakat itu sendiri dikarenakan kurang fahamnya masyarakat dengan program Keluarga Berencana tersebut untuk pemahaman kepada masyarakat pemerintah perlu melakukan kordinasi dengan baik antara masyarakat dan tenagan pelaksana dalam hal ini tenaga medis dan perlunya sosialisasi dari pemerintah yang baik kepada masyarakat.

Efisiensi (efficlency) berkenan dengan jumlah usaha dan seberapa lama waktu yang diperlukan untuk mencapai target program semakin singkat waktu yang ditempuh dan hasil yang diinginkan tercapai maka semakin baik diperlukan untuk menghasilkan tingkat efektifitas tertentu. Efisiensi yang merupakan sinonim dari rasionalitas ekonomi, adalah merupakan hubungan antara efektivitas dan usaha, yang terahir umumnya diukur dari ongkos moneter.

Untuk instansi pemerintah yang menjadi pelayan publik pengukuran 
kinerjanya menjadi sangat penting untuk menilai seberapajauh pelayanan yang diberikan kepada masyarakat, apakah sudah memenuhi harapan masyarakat selaku pengguna jasa pelayanan dalam hal pemberian pelayanan, selain itu juga pengukuran kinerja dapat dijadikan tolak ukur apakah masyarakat sudah puas dengan kinerja pelayanan yang ada. Dengan adanya informasi tentang penilaian kinerja tersebut dapat dijadikan acuan untuk memperbaiki kinerja agar lebih sistematis dan tepat arah sehingga tujuan ataupun misi organisasi bisa tercapai dan pelayanan publik yang diberikan bisa lebih optimal. Dengan adanya kinerja birokrasi yang tinggi maka organisasi tersebut akan berjalan secara efektif, efisien dan responsif dalam memberikan pelayanan.

Berbicara masalah pendidikan yang didapatkan oleh masyarakat dalam program yang diluncurkan oleh pemerintah Kabupaten Enrekang dalam program keluarga berencana Keluarga Berencana masyarakat dapat pendidikan moral mengenai kehidupan dalam keharmonisan keluarga kecil antara bapak, ibu dan anak banyak dalam kalangan masyarakat yang tidak memahami pentingnya Keluarga Berencana dan diantaranya adalah keluarga dapat melakukan kontrol kehamilan dan kelahiran anak serta dapat memberikan perhatian pada anak yang masih butuh perhatian yang penuh dari seorang ibu sebelum hamil dan melahirkan lagi akan berpengaruh terhadap kesehatan ibu dan anak jika jenjang kelahiran terlalu mepet atau tidak rengan pada usia anak ideal sebelum punya anak lagi akan sangat berpengaruh terhadap kesehatan kehamilan Ibu.

Usaha yang dilakukan untuk menghasilkan target pencapaian tujuan dengan memperhatikan hal-hal yang diperlukan sehingga suatu kebijakan dapat dilaksanakan dengan baik, berkaitan dengan usaha yang dilakukan UPT dan system serta prosedur dalam pelayanan $\mathrm{KB}$.

Efesiensi yang telah ada sudah berjalan dengan baik diukur dari efesiensi waktu dan biaya dan 
kemampuan serta kemauan masyarakat dengan program KB sudah jauh lebih baik dari beberapa tahun yang lalu yang dimagsud disini adalah bagaimana cara mencapai tujuan yang ingin dihasilkan dengan proses yang baik dan tidak banyak hal-hal yang merugikan yang timbul pada program tersebut untuk mengetahui gejalagejala yang timbul maka dibutuhkan proses pelaksanaan dan salah satu indikator yang ingin dicapai adalah efesiensi proses pelayanan $\mathrm{KB}$ dengan baik dan proses kerja yang baik dan benar

Kecukupan berkenaan dengan seberapa jauh suatu tingkat efektivitas memuaskan kebutuhan, nilai atau kesempatan yang menumbuhkan adanya masalah. Kriteria kecukupan menekankan pada kuatnya hubungan antara alternatif kebijakan dan hasil yang diharapkan.

Dengan kata lain kecukupan berarti biaya tetap dan efektivitas tetap. Atau dengan kata lain kecukupan dapat terpenuhi dengan adanya rasa kepuasan dari masyarakat yang mengunakan Program Keluarga
Berencana dengan seluruh proses pelayanan efek yang dirasakan oleh masyarakat serta masyarakat juga merasa paus ketika ada keluhan yang dirasakan dengan adanya kelainan pada penguna KB bidan atau pelaksana yang bertangun jawab dapat menyelesaikan permasalahan dari masyarakat tersebut sebagai bentuk respon cepat untuk mensukseskan Program Keluarga Berencana

Dalam pencapaian program dikatakan cukup apabilah seluruh prosedur berjalan baik dari hasil kesimpulan penelitian dapat ditarik kesimpulan program $\mathrm{KB}$ sudah baik dan mendapat kepuasan di kalangan masyarakat terkhusus pada pengunanya.

Peralatan erat hubungannya dengan konsepsi yang saling bersaing, yaitu keadilan atau kewajaran dasar yang memadai untuk mendistribusikan sumber daya dalam masyarakat. Tujuan dari program ini adalah menurunkan AKI dan AKB serta pelayanan yang memuaskan dan penngkatan keluarga sehat dan 
sejahtera. Atas dasar kesamaan dan pemerataan

Program Keluarga Berencana KB di kecamatan Baraka kabupaten engrekang pemerataan pelayanan sudah berjalan dengan sesuai dengan yang diharapkan dalam pencapaian program namun demikian belum dapat disimpulkan dengan jika program berjalan dengan sempurna karena masih ada berbagai hal yang perlu untuk dibenahi dengan baik untuk mencapai kesempurnaan program tapi secara umum program ini berhasil dalam pemerataan pelayanan yang baik.

Responsivitas berkenaan dengan seberapa jauh suatu kebijakan dapat memuaskan kebutuhan masyarakat sebagai sasaran target kebijakan apakah mendapatkan pelayanan dengan baik atau tidak, preferensi atau nilai-nilai kelompok masyarakat tertentu. Responsivitas berbicara tentang apakah kriteria efektivitas, efisiensi, kecukupan dan kesamaan secara nyata mencerminkan kebutuhan, preferensi, dan nilai dari kelompok-kelompok tertentu.
Responsivitas pada program $\mathrm{KB}$ ini relatif baik.

Pelaksanaan pada perumusan dilakukan pada sisi post-tindakan, yaitu lebih dari proses perumusan dari pada muatan kebijakan yang bisanya hanya menilai apakah prosesnya sudah sesuai dengan prosedur yang sudah disepakati dalam rangka pengawasan harus dapat memberikan informasi objektif mengenai tingkat capaian pelaksanaan kebijakan pada momentum atau dalam jangka waktu tertentu.

Ketepatan secara dekat yang berhubungan dengan rasionalitas subtantif, karena pertanyaan tentang ketepatan kebijakan tidak berkenaan dengan suatu kriteria individu tetapi dua atau lebih kriteria secara bersama-sama ketepatan merujuk pada nilai atau tujuan-tujuan program dan kuatnya asumsi yang melandasi tujuan dalam sebuah kebijakan pablik melihat dari segi sasaran apakah sudah tepat sasarana.

Dalam aspek ketepatan sasaran dari program keluarga berencana 
sudah berjalan dengan baik dengan kesimpulan dari informan yang mengutarakan kepuasannya terhadap program keluarga berencana dan proses respon pelayanan yang diberikan oleh pemerintah dan tenagan medis yang terkait serta seluruh unsure elemen yang berpengaruh dalam Program Keluarga Berencana KB di Kecamatan Baraka Kabupaten engrekang.

Kemampuan kerja setiap
individu yang mencakup aspek
pengetahuan keterampilan dan sikap
kerja yang sesuai dengan standar
yang ditetapkan yang perlu difahami
dalam program kebijakan
pemerintah adalah penguasaan
terhadap tiga jenis kemampuan
yaitu, pengetahuan (knowledge
science) keterampilan teknis (skill,
teknologi)dan sikap prilaku
(attitude). Dalam menjalankan suatu
kebijakan hal yang paling mendasar
adalah ketepatan atau sasaran untuk
program tersebut.

Dampak kebijakan adalah sesuatu yang ditimbulkan dalam masyarakat sebagai sasaran dari kebijakan tersebut apakah sudah berjalan dengan baik atau tidak dan apakah dalam program sudah mendapatkan kepuasan dari masyarakat sebagai pengguna kebijakan.

Kesehatan adalah kebutuhan masyarakat dalam kehidupan keseharian mengapa membahas masalah kesehatan dalam penelitian ini erat kaitanya dengan program yang diterapkan kepada masyarakat penguna Keluarga Berencana karena kita akan berbicara masalah dampak yang akan ditimbulkan dari program pengunaan $\mathrm{KB}$ oleh masyarakat dan bagaimana cara menanganan medis yang seharusnya didapatakan oleh penguna program jika terdapat keluhan

Berdasarkan hasil penelitian, hambatan dari tingkatnya angka kelahiran dan angka kematian kini sekrang sudah dapat terkendali karena adanya kebijakan oleh pemerintah yang telah mengeluarkan adanya program KB. Dimana disi pemerintah telah berikan solusi bahwa dua anak cukup. 
Berbicara masalah pendidikan yang didapatkan oleh masyarakat dalam program yang diluncurkan oleh pemerintah Kabupaten Enrekang dalam program keluarga berencana KB masyarakat dapat pendidikan moral mengenai kehidupan dalam keharmonisan keluarga kecil antara bapak, ibu dan anak banyak dalam kalangan masyarakat yang tidak memahami pengtinnya $\mathrm{KB}$ dan diantaranya adalah keluarga dapat melakukan kontrol kehamilan dan kelahiran anak serta dapat memberikan perhatian pada anak yang masih butuh perhatian yang penuh dari seorang ibu sebelum hamil dan melahirkan lagi dan akan berpengaruh terhadap kesehatan ibu dan anak.

Peningkatan kesehatan keluarga terutama pada Ibu, dan ini yang harus diberikan pemahaman pada masyarakat jika setiap tahun angka kematian Ibu dan Anak meningkat yang diakibatkan pola hamil dan melahirkan tidak tepat dan pemahaman pada masyarakat banyak anak banyak reseki itu adalah salah banyak anak tidak apa-apa asal pola hamil dan melahirkan tepat.

Pencapaian target jumlah peserta KB dapat menjadi tolak ukur efektifitas dari program KB di Kecamatan Baraka terhadap hasil (akibat) yang diharapkan dari Kecamatan Baraka, Sudah sejauh mana Kecamatan Baraka sebagai pelaksana program KB untuk meningkatkan jumlah peserta KB di Kecamatan Baraka, serta hambatan yang menjadi tantangan dalam upaya pelaksanaan Program KB secara maksimal.

Berbicara masalah ekonomi dalam penelitian ini dapat disimpulkan bahwa dalam program keluarga berencana atau KB masyarakat sering menjadikan alasan kenapa tidak mengikuti program Keluarga Berencana karena alasan faktor ekonomi mahalnya pelayanan medis yang diberlakukan oleh pihak medis tapi dengan adanya program ini tidak ada alasan lagi dengan ekonomi karena program Keluarga Berencana atau KB Di Kecamatan Baraka Kabupaten Enrekang 
dilaksanakan dan memberikan pelayanan secara geratis dan CumaCuma tanpa dipungut biaya sama sekali.

Kecukupan berkenaan dengan seberapa jauh suatu tingkat efektivitas memuaskan kebutuhan, nilai atau kesempatan yang menumbuhkan adanya masalah. Kriteria kecukupan menekankan pada kuatnya hubungan antara alternatif kebijakan dan hasil yang diharapkan.

Pemerataan erat hubungannya dengan konsepsi yang saling bersaing, yaitu keadilan atau kewajaran dasar yang memadai untuk mendistribusikan sumber daya dalam masyarakat. Tujuan dari program ini adalah menurunkan AKI dan AKB serta pelayanan yang memuaskan dan penngkatan keluarga sehat dan sejahtera. Atas dasar kesamaan dan pemerataan.

Program keluarga berencana KB tidak ada pengaruh dari segi ekonomi masyarakat karena program ini adalah program yang prorakyat dari pemerintah Kabupaten Engrekan sehingga program ini adalah program yang sudah tepat dan baik untuk masyarakat.

Berhasilnya suatu kinerja itu dapat dinilai dari setiap staf -staf yang kini telah setia dan penuh keikhlasan untuk bekerja demi mencapai tujuan yang mereka inginkan. Kebijakan pemerintah tersebut memiliki keyakinan kepada pekerja untuk lebih semangat lagi bekerja.

Hambatan yang di hadapi oleh peserta KB yaitu tempat pelayanan dimana tempat atau ruang tersebut masih perlu pembenahan agar peserta KB tidak kewalahan lagi untuk mencari tempat untuk duduk menunggu antrian pelayanan tersebut di Kantor Pelayanan Program Keluarga Berencana KB.

Mengenai sarana dan prasarana yang digunakan di Kantor Balai Penyuluhan Keluarga Berencana sudah sesuai dengan apa yang dibutuhkan pegawai demi terlaksananya pelayanan dengan baik sehingga mendapat tanggapan baik dari masyarakat pengguna Program Keluarga Berencana (KB). 


\section{KESIMPULAN}

Penelitian mengenai Pelaksanaan Program Keluarga Berencana di Kecamatan Baraka, maka berdasarkan kebijakan dapat ditarik kesimpulan melalui 6 (enam) criteria yang dapat pelaksanaan suatu kebijakan dapat diketahui berhasil atau tidak. Berdasarkan tujuan yang terdapat pada latar belakang tentang mengevaluasi program keluarga berencana di Kecamatan Baraka, dapat ditarik kesimpulan.

Efektivitas, dalam konteks efektifitas program sudah berjalan dengan baik dan tepat pada sasaran, hambatan terdapat pada calon peserta KB itu sendiri karena masih memiliki pola pikir yang sederhana, acuh terhadap kesehatan ibu dan anak.

\section{Efisiensi, dari kesimpulan} keseluruhan dalam proses penelitian selaku peneliti dapat menyipulkan program KB berhasil dengan baik dalam masyarakat kecamatan Baraka kabupaten engrekang. Ditandai dengan program berjalan dengan baik dan program KB ini menjadi program pemerintah yang digeratiskan untuk masyarakat dan keberhasilannya cukup memuaskan serta pelayanan yang memuaskan masyarakat.

Kecukupan, selaku penulis dapat menarik kesimpulan bahwa kepuasan masyarakat dapat menandakan dalam pencapaian program dikatakan cukup apabilah seluruh prosedur berjalan baik dapat ditarik kesimpulan program KB sudah baik dan mendapat kepuasan di kalangan masyarakat terkhusus pada pengunanya.

Pemerataan, dapat menarik kesimpulan bahwa program Keluarga Berencana KB di kecamatan Baraka pemerataan pelayanan sudah berjalan sesuai dengan yang diharapkan dalam pencapaian program tapi masih banyak hal yang perluh pembenahan akses program untuk masyarakat agar masyarakat memahami dengan baik program yang telah diterapkan pemerintah.

Ketetapan, bahwa masyarakat mendapatkan kepuasan dalam 
program keluarga berencana $\mathrm{KB}$ yang menandakan keberhasilan program KB dengan adanya kepuasan masyarakat dalam suatu kebijakan maka hal itu menandakan bahwa ketepatan program sudah terealisasi dengan baik.

Kesehatan, bahwa efek kesehatan yang ditimbulkan tidak ada yang serius selama dalam prosedur yang baik dan dalam pengawasan yang serius dari pihak yang berwenan melakukan pertangun jawaban dalam program KB keluarga berencana. Dalam program KB juga adalah program peningkatan kesehatan keluarga yang perlu untuk mendapat perhatian yang serius.

Ekonomi, program keluarga berencana KB tidak ada pengaruh dari segi ekonomi masyarakat karena program ini adalah program yang prorakyat dari pemerintah Kabupaten Enrekang sehingga program ini adalah program yang sudah tepat dan baik untuk masyarakat.
Kontribusi program $\mathrm{KB}$ dalam pengendalian penduduk sudah optimal dan berjalan dengan baik dan dapat diterima oleh masyarakat dengan baik pelaksanaan program $\mathrm{KB}$ sesuai dengan Undang-Undang 52 tahun 2009 yang telah berjalan di Kecamatan Baraka Kabupaten Enrekang. Perlu adanya kerjasama (team work) antara Petugas Lapangan Keluarga Berencana (KLPB) dan Kader Pos KB untuk saling memantau hasil Program Keluarga Berencana dengan melihat dari berbagai aspek kehidupan dan kepentingan bersama.

\section{DAFTAR PUSTAKA}

Abidin, Zainal, Said. 2012. Kebijakan Publik, Jakarta: Salemba Humanika.

Agustino, Leo. 2012. Dasar-Dasar Kebijakan Publik. Bandung: Alfabeta

Anderson, james E. 1984. Public Policy Making, CBS Collenge Publishing.

Dunn, William N. 2003. Pengantar Analisis Kebijakan Publik Edisi kedua.Yogyakarta : Gajah Mada University Press 
Kolaborasi : Jurnal Administrasi Publik, April 2018Volume 4 Nomor 1

Hartanto,Hanafi.1934. Keluarga Berencana dan Kontrasepsi. Jakarta : Pustaka Sinar Harapan.

Hartanto, H, 2007. Keluarga Berencana dan kontrasepsi. Jakarta: Pustaka Sinar Harapan.

Keban, Yeremias, T. 2004. Enam Dimensi Strategis Administrasi Publik Konsep, Teori dan Isu. Penerbit Gaya Media. Yogyakarta

Mustari,Nuryanti. 2013. Implementasi Kebijakan Publik. Makassar.

Mulyadi, Deddy. 2016. Studi Kebijakan Publik dan Pelayanan Publik. Penerbit Alfabeta. Bandung.

Rifa'I, A, 2007, Pelaksanaan Pembelajaran, Universits Negeri Semarang Press, Semarang. 